\title{
ILEGITIMIDADE DA APLICAÇÃO A AGENTES ESTATAIS DE SANÇÕES FUNDADAS EM SIMPLES “ERRO JURIDICO” 1
}

\author{
Claudio Penedo Madureira ${ }^{2}$
}

\section{Resumo}

O objetivo deste artigo é demonstrar que a estrutura flexível do Direito de nosso tempo torna ilegítima a atribuição a agentes estatais de sanções que decorram de simples divergência na interpretação dos textos normativos ("erro jurídico"). Para atingi-lo, parto da premissa de que o Direito aplicado aos casos concretos é reconstruído pelos intérpretes no campo de sua aplicação, que resulta do ocaso do paradigma normativo liberalburguês (que orientou uma profunda modificação na forma como vinham sendo produzidos os textos legislativos, que passaram a empregar cláusulas gerais e conceitos jurídicos indeterminados), da ascensão da jurisdição constitucional como método de controle da racionalidade e da justiça dos atos legislativos e da constatação teórica de que a incidência jurídica não comporta, em vista desses pressupostos, uma única resposta correta para a solução dos litígios. Essa particularidade da aplicação do Direito impede que os agentes estatais de antecipem, com a necessária segurança, a interpretação jurídica ulteriormente manifestada pelos órgãos de controle e pelo Poder Judiciário, refutando, à míngua da caracterização da voluntariedade da sua conduta e da demonstração da sua culpabilidade, a possibilidade de que thes sejam atribuídas sanções fundadas em "erros jurídicos".

Palavras-chave: Direito; Hermenêutica; Erro jurídico; Agentes Estatais; Sanções.

\section{EXPOSIÇÃO DO PROBLEMA}

O CONJUR noticiou, em 06 de novembro de 2016, que o juiz Sérgio Moro afirmou, em entrevista concedida ao jornal o Estado de São Paulo, que "o Direito não é matemática", e que por isso "não dá para dizer com precisão quando há ou quando não há justa causa para a propositura da ação penal”. Essa sua observação encerra crítica a projeto de lei de abuso de autoridade que tramita no Congresso Nacional, que dispõe, entre outras coisas, sobre a responsabilização de promotores e juízes pela apresentação/recebimento de denúncias quando posteriormente se verificar, no curso dos processos, que não havia justa causa, isto é, que a imputação formulada não merecia prosperar. Para Moro, essa proposta legislativa "possibilitaria que o denunciado entrasse com uma ação penal por abuso de autoridade", por exemplo, quando "o juiz decreta uma prisão e, eventualmente,

\footnotetext{
${ }^{1}$ Este trabalho foi concebido no contexto de pesquisa financiada pela Fundação de Amparo à Pesquisa e Inovação do Espírito Santo - FAPES (Edital no 06/2015 - UNIVERSAL INDIVIDUAL), que estuda "A conciliação como meio alternativo para a resolução de controvérsias jurídicas envolvendo a Fazenda Pública”.

${ }^{2}$ Doutor em Direito pela PUC/SP. Professor do Programa dos cursos de Graduação e Mestrado em Direito da UFES. E-mail: madureira.fmr@gmail.com
} 
essa prisão é revogada, não porque o juiz abusou, mas porque o juiz errou na interpretação da lei". Em suas próprias palavras, "isso de sujeitar o juiz a um processo criminal é o que a gente chama de crime de hermenêutica", que pode colocar membros do Poder Judiciário e do Ministério Público, enquanto autoridades encarregadas da aplicação do Direito, "numa situação em que possivelmente podem sofrer acusações, não por terem agido abusivamente, mas, sim, porque adotaram uma interpretação que eventualmente não prevaleceu nas instâncias recursais ou superiores".

O juiz Sérgio Moro está coberto de razão. De fato, o "Direito não é matemática". A sua realização, conquanto parta da identificação e da seleção dos enunciados prescritivos em tese aplicáveis aos casos concretos, também abarca a interpretação desses textos normativos. Essa atividade cognitiva pressupõe a investigação do real sentido das palavras neles contidas, que se realiza no contexto de uma interpretação contextual (ou sistemática) do ordenamento jurídico, por meio da qual se procura descobrir o sentido da lei (ou o seu espírito) a partir de uma referência do intérprete (ou aplicador do Direito) ao direito positivo quando considerado em sua integridade. No entanto, nesse contexto, também cumpre ao intérprete investigar, à luz das especificidades do ambiente fático que emoldura a contenda, se a norma (abstrata) em tese aplicável está apta a incidir sobre o caso concreto, podendo chegar, num estágio mais avançado, notadamente quando se cogita da incidência de princípios jurídicos, à introdução do elemento axiológico nessa sua tarefa interpretativa, pela via de uma sua referência a valores juridicizados pelo legislador. Refiro-me, no ponto, ao caráter normativo dessa atividade interpretativa, que sugere que o Direito aplicado aos casos concretos é reconstruído pelos intérpretes no campo de sua aplicação, e resulta do ocaso do paradigma normativo liberal-burguês (que orientou uma profunda modificação na forma como vinham sendo produzidos os textos legislativos, que passaram a empregar cláusulas gerais e conceitos jurídicos indeterminados), da ascensão da jurisdição constitucional como método de controle da racionalidade e da justiça dos atos legislativos e da constatação teórica de que a incidência jurídica não comporta, em vista desses pressupostos, uma única resposta correta para a solução dos litígios. O que ocorre é que, como terei a oportunidade de adiante expor e demonstrar, os intérpretes, dada a possibilidade da configuração de respostas díspares sobre como deve se dar a aplicação do Direito, não dispõem de meios para antecipar, com a necessária segurança, a interpretação que prevalecerá no curso do processo.

Todavia, esse raciocínio desenvolvido por Moro não se aplica única e exclusivamente a juízes e promotores. Em rigor, como todo e qualquer intérprete é afetado por essa estrutura flexível característica do Direito de nosso tempo, também os advogados e, por extensão, as pessoas que seguem suas orientações jurídicas têm dificuldades para antecipar, nos casos concretos, como se posicionarão no futuro os órgãos de controle (com destaque para a atuação do Ministério Público e dos Tribunais de Contas) e o Poder Judiciário.

O tema assume relevância ainda maior quando se tem em vista as atividades desempenhadas pelos 
advogados da Fazenda Pública (comumente chamados advogados públicos, ou procuradores) e pelos gestores e servidores que por eles são orientados, no exercício da função administrativa, com vistas à prática de atos concretos, como a aquisição de bens e serviços, a concretização de atuações administrativas, a concessão de benefícios fiscais, etc. Com efeito, a Lei no 8.429/1992 (Lei de Improbidade Administrativa) dispõe, em seu artigo 11, sobre a possibilidade da responsabilização de agentes estatais por contrariedade a princípios da Administração, entre eles o princípio da legalidade (CRFB, art. 37, caput). Além disso, é relativamente comum que esses agentes estatais sejam instados ao polo passivo de processos em curso nos Tribunais de Contas, inclusive para que lhes sejam atribuídas sanções pessoais, quando se cogita da ilegalidade dos atos praticados. A premissa que orienta essas posturas é que da ilegalidade do ato resulta, ipso facto, a possibilidade da atribuição de sanções aos agentes estatais direta ou indiretamente responsáveis pela sua confecção.

Este artigo tem por objetivo refutar essa premissa, pela via da demonstração, fundada em elementos científicos e jurídico-normativos, de que o caráter flexível da aplicação do Direito na Era Contemporânea impede a atribuição de sanções por "erro jurídico" não apenas a juízes e promotores (como denunciou, muito oportunamente, o juiz Sérgio Moro), mas também aos advogados públicos que orientam atividade administrativa e, por extensão, aos gestores e servidores que por eles são orientados na execução de suas tarefas, à mingua da caracterização, nas hipóteses fáticas em que se lhes imputa tão somente a veiculação de interpretação jurídica que ulteriormente se considerou equivocada e/ou a prática de atos concretos fundados em manifestações técnicas da procuradoria, da voluntariedade da sua conduta e da efetiva demonstração da sua culpabilidade.

\section{O CARÁTER NORMATIVO DA ATIVIDADE COGNITIVA DESENVOLVIDA PELOS INTÉRPRETES NO CAMPO DA APLICAÇÃO DO DIREITO}

Norberto Bobbio, em obra clássica dedicada ao estudo do positivismo jurídico, assevera que "interpretar significa remontar do signo (signum) à coisa significada (designatum), isto é, compreender o significado do signo, individualizando a coisa por este indicada" (1995, p. 212). O que com isso quis dizer o professor italiano é que "a linguagem humana (falada ou escrita) é um complexo de signos" e, assim, exige interpretação, já que "a relação existente entre o signo e a coisa significada (neste caso, entre a palavra e a ideia) não é uma relação necessária, mas puramente convencional, tanto que a mesma ideia pode ser expressa de modos diversos" (BOBBIO, 1995, p. 212 213). Daí a sua conclusão quanto a haver um certo desajuste entre a ideia e a palavra, que decorre da circunstância de a ideia ser mais rica, mais complexa, mais articulada do que a palavra utilizada para exprimi-la (BOBBIO, 1995, p. 212-213).

Semelhante observação, conquanto singela, é melhor aclarada no contexto da semiótica, na designação proposta por Charles Sanders Pierce (1990), ou semiologia, tal como denominada por Ferdinand de Saussure 
(2002), ramo de conhecimento qualificado por Luiz Alberto Warat como teoria geral dos sistemas sígnicos (1995, p. 11). O signo, em tal conceituação, é a unidade mínima de comunicação; e é composto por três elementos: o suporte físico, o significado e o significante. Nesse contexto, o suporte físico é designado como a expressão material do signo, o significado como o seu objeto real ou imaginário e o significante como a ideia ou conceito que os intérpretes formam acerca do suporte físico. Se transpusermos esse modelo semiótico para o campo da interpretação e aplicação do Direito, teremos no direito positivo o suporte físico, nas pré-compreensões dos intérpretes acerca da real conformação da norma abstrata em tese aplicável ao caso (direito) e/ou da conduta humana sobre a qual essa norma hipoteticamente incide (fato) o seu significado e na norma jurídica (concreta) incidente sobre o caso, então construída (ou revelada) por meio de exercício hermenêutico, a significação que os intérpretes/aplicadores atribuem ao seu objeto cognoscente (cf. CARVALHO, 1997, p. 06-07).

Destrinchada, nesses termos, a atividade cognitiva exercida pelos intérpretes com vistas à compreensão/aplicação do direito positivado dos textos normativos, torna-se evidente que o que Bobbio quis dizer quando referiu a existência de um certo desajuste entre a ideia (significante) e a palavra (suporte físico) foi que o Direito aplicado ao caso decidido pode não se apresentar como imagem espectral do direito expressado nos enunciados prescritivos aprovados pelo Parlamento. Com efeito, se a significação remonta à ideia (ou conceito) que o intérprete tem do suporte físico analisado (no caso, do direito positivo), e se essa percepção (da significação) é mutável no ambiente cognitivo do direito, em vista da compreensão do intérprete acerca dos conceitos jurídicos expressados na norma jurídica em tese aplicável (significado), pode ocorrer, na casuística, de a norma concreta a ser revelada não reproduzir ipsis literis o que resta prescrito nos textos legais. E tal ocorre, ainda, porque essa ideia (significação) formada pelo intérprete (aplicador) acerca do seu objeto de análise (o direito positivo) também é influenciada pelas peculiaridades do caso concreto, isto é, porque a sua atividade quando procura no ordenamento jurídico-positivo a norma abstrata capaz de regular o caso submetido à sua avaliação não se dissocia da decomposição do problema apresentado e da identificação, nos fatos, de caracteres e notas capazes de efetivar a ligação do fenômeno aos conceitos.

Essa perspectiva é aceita e sustentada inclusive por Hans Kelsen, que se qualifica, sem qualquer margem a dúvidas, como um dos teóricos mais influentes entre os positivistas da Era Contemporânea, e que concebe, em sua Teoria Pura do Direito, a norma jurídica como esquema de interpretação, dispondo, no corpo daquela sua obra seminal, que "o juízo em que se enuncia que um ato de conduta humana constitui ato jurídico (ou antijurídico) é o resultado de uma interpretação específica, a saber, de uma interpretação normativa" (2006, p. 04). Kelsen adere à proposição de que o direito positivo figura como objeto da atividade cognitiva desenvolvida pelos intérpretes, qualificando-o como "ordem normativa da conduta humana, ou seja, um sistema de normas que regulam o comportamento humano" (2006, p. 05). E acentua, noutra passagem, que: 
[...] somente a falta de compreensão da função normativa da decisão judicial, o preconceito de que o direito apenas consta de normas gerais, a ignorância da norma jurídica individual, obscureceu o fato de que a decisão judicial é tão-só a continuação do processo de criação da norma jurídica e conduziu ao erro de ver nela apenas a função declarativa. (2006, p. 265)

Disso resulta que, mesmo sob a ótica estrita da teoria pura do direito, é irrefutável a afirmação de que os intérpretes põem norma no sistema, embora um tipo bastante específico de norma jurídica, comumente chamada de norma concreta, e adiante designada por José Joaquim Gomes de Canotilho como “norma de decisão” (2000, p. 1.221).

\section{A superação do paradigma normativo liberal-burguês}

Semelhante proposição é reforçada por um dado histórico, consistente na superação do paradigma normativo liberal-burguês, outrora concebido no contexto do movimento revolucionário Francês do Século XVIII, e adiante propalado pelos teóricos do positivismo. Esse paradigma teve especial importância para a consolidação do Direito enquanto Ciência (ZANETI JÚNIOR, 2007, p. 160), conforme se observa da seguinte passagem da obra de Miguel Reale:

A Revolução Francesa teve vários reflexos e efeitos que não podemos, aqui, examinar. Dentre as suas consequências, devemos, entretanto, destacar uma: foi na época da Revolução Francesa que se advogou a necessidade de um Direito único para a totalidade da Nação. Anteriormente, havia um Direito que resolvia os problemas locais, assim, como havia um Direito de classes, um para a plebe e outro para a nobreza e o clero, com revoltantes desigualdades.

Com a Revolução Francesa, por conseguinte, surge uma realidade histórica de cuja importância muitas vezes nos olvidamos: o Direito nacional, um direito único para cada Nação, Direito este perante o qual todos são iguais. O princípio da igualdade perante a lei pressupõe um outro: o da existência de um único Direito para todos que habitam num mesmo território.

Com o advento do Código Civil francês e dos que foram elaborados, tomando-o como modelo, passaram os juristas a ter um Direito certo para todos e suscetível de indagação lógica e segura. A Ciência do Direito encontrou, assim, base para poder atingir notável grau de sistematização. Não mais o comentário ocasional, para atender a circunstâncias locais, mas um sistema que distribuía a matéria segundo uma ordenação lógica, permitindo a interpretação, a construção e a compreensão unitária das regras vigentes, segundo princípios de caráter geral. (1998, p. 152-153)

Refiro-me, nesse ponto, ao período do Estado Liberal, que se estende até a Primeira Guerra Mundial, e que se caracteriza pela separação dos Poderes (em que, teoricamente, o Poder Legislativo assume a precedência e o Poder Judiciário resta, na prática, politicamente neutralizado) e pela ascensão do princípio da legalidade e da subsunção racional-formal (que veda a decisão contra legem, fazendo com que os Tribunais se movimentem em um quadro jurídico-político pré-constituído) (cf. ZANETI JÚNIOR, 2007, p. 160; SANTOS; MARQUES; PEDROZO, 1996, p. 32-33). Ganha corpo, nesse contexto, imposição a que os juízes se pronunciem como “a boca da lei", isto é, que tenham atuação restrita à aplicação do Direito tal como prescrito nos textos legais (cf. ZANETIJÚNIOR, 2004, p. 44). 
No entanto, semelhante aspiração teórica, concebida a par da necessidade de se atribuir maior segurança jurídica aos negócios da então emergente classe social burguesa, lastreava-se em um liberalismo que foi duramente questionado ao início do Século XX, notadamente após a propagação do socialismo no Leste Europeu e a consolidação em algumas nações do Velho Continente do que doravante se convencionou chamar Estado Social (cf. BONAVIDES, p. $72-73$ e p. 202-203). Daí que, se a Modernidade é marcada pela preocupação dos filósofos com o problema da justificação da obrigação política e se singulariza pela identificação do Direito (e, por conseguinte, da própria justiça) com o direito positivo, na Era Contemporânea presenciamos uma reformulação do Direito das nações, que passa a ter como pano de fundo a questão social (cf. ZANETI JÚNIOR, 2007, p. 160; SANTOS; MARQUES; PEDROZO, 1996, p. 32-33; MAFFETONE; VECA, 2005, p. 227). Pelas mãos da questão social a definição do conceito de justiça reorientou-se no sentido da sua afirmação como uma justiça distributiva. Nesse contexto, o significado e o valor de uma teoria da justiça passaram a se relacionar com a sua capacidade de satisfazer fins e expectativas sociais (cf. MAFFETONE; VECA, 2005, p. 227), o que induziu a conformação, a lado daquela visão liberal-positivista anteriormente referida (que foi inaugurada a partir da Revolução Francesa e que jamais foi abandonada pelos teóricos do Direito), de uma acepção social-utilitarista do Direito e da justiça (cf. NADER, 1999, p. 130-132).

O confronto entre essas duas distintas visões de mundo se acentuou ao fim da Segunda Guerra Mundial, ocasião em que se principiou, a par da polarização entre os regimes Capitalista (representado ideologicamente pelo American Way Of Life) e Socialista (capitaneado pela antiga União das Repúblicas Socialistas Soviéticas), a chamada Guerra Fria. Foi, assim, no contexto da contraposição entre os paradigmas liberal-burguês e socialista que se consolidou, a partir do último quadrante do século passado, notadamente em vista do que se convencionou chamar "a crise do Poder Legislativo", uma nova forma de pensar o Direito, que singulariza as reflexões jurídicas características de nosso tempo.

Reporto-me, aqui, à passagem do Estado Liberal para o Estado Social (Welfare State), que se qualifica, entre outros fatores, pela inflação legislativa decorrente do surgimento e proliferação de novos direitos, em especial de direitos coletivos, e que ocasionou, adiante, a descodificação, com gradual perda de coerência (ou de sistematicidade) do ordenamento jurídico (cf. ZANETI JÚNIOR, 2007, p. 160-161; SANTOS; MARQUES; PEDROZO, 1996, p. 32-34). A partir de então se desenvolveu uma verdadeira revolução no método de construção política dos textos normativos, que paulatinamente passaram a ser representados em termos abertos (cf. HABERMAS, 2003, p. 174), mediante o emprego de cláusulas gerais e conceitos jurídicos indeterminados (cf. MAZZEI, 2006, p. 34). Essa virada de paradigma é acentuada, nos termos seguintes, por Francisco Vieira Lima

\footnotetext{
${ }^{3}$ Que resultou, entre outros fatores, da derrocada dos regimes nazifascistas que se espalharam pela Europa antes e ao longo daquele conflito bélico - que então se legitimavam sob o império do direito positivo - e da profusão de novas aspirações e novos direitos como decorrência da "questão social" (a propósito, cf., por todos: TUCCI, 2004, p. 179).
} 
Neto:

Essa atitude encontra ampla repercussão no direito atual, momento de grande insegurança e incerteza, no qual os modelos jurídicos, expressos por meio de dispositivos claros, precisos, de conteúdo previamente determinado cedem lugar aos conceitos jurídicos indeterminados, às cláusulas gerais, aos princípios, figuras dotadas de extrema vagueza semântica, que permitem ao intérprete construir seu significado e lhes dar concretização no caso em análise, decisão que não vale necessariamente para um outro caso semelhante a ser julgado no futuro. (2008, p. 39)

Tamanha indeterminação do Direito culmina por repercutir nas relações entre os Poderes, pois, em tal conjuntura, a lei, ou a sua intelecção, passou a exigir "acabamento do Poder Judiciário” que, de seu turno, viu-se "provocado pelas instituições e pela sociedade civil a estabelecer o sentido ou a completar o significado de uma legislação" que então assumia conformação e motivações claramente distintas às da certeza jurídica, como disseram Luiz Werneck Vianna, Manuel Palácios Cunha Melo e Marcelo Baumann Burgos (1999, p. 21). Daí a conclusão desses cientistas políticos quanto a haver o Poder Judiciário sido investido no papel de legislador implícito pela própria conformação da lei no Estado Social (VIANNA; MELO; Burgos, 1999, p. 21).

\section{A jurisdição constitucional e o controle da racionalidade e da justiça dos atos legislativos}

Mas esse não foi, certamente, o único fator a induzir a superação do paradigma normativo liberalburguês, que se acentua, e se consolida, a partir da constitucionalização dos direitos e, sobretudo, da possibilidade teórica de juízes e tribunais virem a deixar de aplicar leis que se mostrarem desconformes à Constituição, isto é, que contraditem as suas regras, os seus princípios e os valores subjacentes ao seu texto, entre eles o valor justiça. Posto isso, não há dúvidas de que se "o direito inclui, hoje, uma forte dose de indeterminação", tal não decorre apenas da "profusão de normas de tecitura aberta, que não contêm a fattispeciee a consequência jurídica de forma determinada" e que "abrem espaço para sua determinação judicial", devendo-se, também, à "sua submissão aos parâmetros de justiça, aferíveis da Constituição” (ZANETI JÚNIOR, 2007, p. 56).

O que se deu foi que não bastasse a circunstância, dantes mencionada, de a substituição da matriz racionalista apodítica do paradigma legalista por técnicas legislativas mais abertas haver obrigado o juiz à criação no caso concreto e a doutrina à busca de modelos normativos jurisprudenciais para conferir certa estabilidade ao direito aplicado, a constitucionalização dos direitos e dos princípios ocorrida no período imediatamente posterior ao segundo pós-guerra ruiu em definitivo o Estado de Direito Legalista do século XIX (cf. ZANETI JÚNIOR, 2007, p. 54). A partir de então "o direito se constitucionalizou, no conhecido movimento do pós-positivismo, com a principialização da Constituição [...] e a sua renovada postura de elemento unificador da ordem normativa”, de modo que "todo o direito hoje ou é direito constitucional (conforme à constituição) ou não é direito" (ZANETI JÚNIOR, 2007, p. 54). Por esse motivo, a jurisdição constitucional, ou a sua consolidação nos Países que adotaram, sob influência da experiência jurídica norte-americana, a sistemática do judicial review, também tem 
influência decisiva na derrogação do paradigma normativo liberal-burguês (cf. ALEXY, 2007; GADAMER, 2000; GRAU, 2005; STRECK, 2006).

A essa compreensão agrega-se a imensa potencialidade reconstrutiva de nosso regime híbrido de controle da constitucionalidade das leis, o qual, mais do que possibilita aos órgãos jurisdicionais a reconstrução do direito positivo, sob a mediação dessa sua atividade intelectiva, a eles impõe o cumprimento de semelhante desiderato, já que sua realização é pressuposto necessário à preservação da integridade do ordenamento jurídico (cf. ZANETI JÚNIOR, 2007, p. 55). É que o regime constitucional brasileiro, quando adotou, a partir da Constituição de 1891, o modelo norte-americano de controle judicial do poder estatal (judicial review), conferiu a todo e qualquer magistrado difuso ao longo do território nacional a prerrogativa de proceder ao controle da constitucionalidade dos atos normativos e concretos dimanados pelos Entes Estatais (cf. MITIDIERO, 2007, p. 25), abrindo espaço, então, para que se discutisse judicialmente não apenas a subsunção das atividades públicas e privadas aos textos legais (controle de legalidade), mas, também, a sua conformidade ao texto da Constituição (controle da validade constitucional).

Essa atividade cognitiva é potencializada no regime da Carta Política de 1988, que arrola a realização concreta da justiça entre os objetivos fundamentais da República (art. $3^{\circ}$, I) e que assimila como direito fundamental do cidadão o princípio do devido processo legal (art. $5^{\circ}, \mathrm{LIV}$ e LV), cujo aspecto substancial impõe a realização concreta do direito material deduzido em juízo (cf. CANOTILHO, 2000, p. 494-495) não mais a partir da tão-só subsunção dos fatos concretos ao direito positivo abstrato, mas por meio de uma aplicação temperada dos textos jurídicos às peculiaridades do caso, o que implica, necessariamente, a interpretação das proposições normativas abstratas em tese aplicáveis à contenda sob a mediação dos standards da razoabilidade e da proporcionalidade (cf. ZANETTI JÚNIOR, 2007, p. 187-188; ÁVILA, 2005, p. 109-110). Essa particularidade da conformação de seu texto permite concluir que a Constituição brasileira estendeu o controle da validade constitucional dos atos concretos e normativos para além da sua simples conformidade aos textos jurídicos, impondo, a bem da verdade, ao Poder Judiciário, o controle da justiça (ou da justeza) das escolhas assumidas pelo Poder Público, inclusive daquelas estabelecidas em âmbito legislativo (cf. MITIDIERO, 2009, p. 40-41).

\section{Flexibilização do Direito e inexistência de uma única resposta correta}

A isso se acrescenta, ainda, a notável flexibilização do Direito, no campo da sua aplicação, proporcionada pela distinção teórica entre regras e princípios jurídicos, inaugurada a partir da célebre dissensão entre Hart (1994) e Dworkin (2002). Quanto ao particular, recobro a lição de Humberto Ávila quando afirma, referindo-se ao magistério de Dworkin, que "as regras são aplicadas ao modo tudo ou nada (all-or-nothing)", de maneira que havendo colisão entre elas, uma delas deve ser considerada inválida; ao passo que os princípios "não determinam 
absolutamente a decisão, mas somente contêm fundamentos, os quais devem ser conjugados com outros fundamentos provenientes de outros princípios" (2005, p. 28). Ávila expressa, nesse contexto, que os princípios jurídicos introduzem os valores no campo da aplicação do Direito, dispondo, a propósito, que "os valores constituem o aspecto axiológico das normas, na medida em que indicam que algo é bom e, por isso, digno de ser buscado ou preservado", ao passo que "os princípios constituem o aspecto deontológico dos valores, pois, além de demonstrarem que algo vale a pena ser buscado, determinam que esse estado de coisas deve ser promovido" (2005, p. 95).

Por todas essas circunstâncias, o Direito de nosso tempo tornou-se mais flexível, ou talvez mais suave, como sugere Gustavo Zagrebelsky (1992). Assim, conforme variam os intérpretes, a interpretação do Direito pode resultar em diferentes soluções jurídicas para um mesmo problema. Com efeito, na precisa alegoria construída por Eros Roberto Grau, "dá-se na interpretação de textos normativos algo análogo ao que se passa na interpretação musical" (2005, p. 36). Grau observa, quanto a esse pormenor, que "não há uma única interpretação correta (exata) da Sexta Sinfonia de Beethoven", aduzindo, ao ensejo, que "a Pastoral regida por Toscano, com a Sinfônica de Milão, é diferente da Pastoral regida por Von Karajan, com a Filarmônica de Berlim", e que "não obstante uma seja mais romântica, mais derramada, a outra mais longilínea, as duas são autênticas - e corretas" (2005, p. 36). Com essas considerações, esse professor paulista rejeita "a existência de uma única resposta correta (verdadeira, portanto) para o caso jurídico - ainda que o intérprete esteja, através dos princípios, vinculado pelo sistema jurídico" (GRAU, 2005, p. 36). Enfim, podem surgir, nos casos concretos, soluções distintas para o mesmo problema, dada a possibilidade de que se estabeleçam, na casuística, desacordos interpretativos sobre as questões decididas, que se fundamentam, pelas razões dantes expostas, no caráter flexível da aplicação do Direito na Era Contemporânea.

\section{ILEGITIMIDADE DA IMPUTAÇÃO DE SANÇÕES POR “ERROS JURÍDICOS” A AGENTES ESTATAIS}

Esses elementos, quando conjugados, fomentaram uma expressiva flexibilização na aplicação do Direito de nosso tempo. Essa particularidade da incidência jurídica priva os intérpretes de antecipar, com a necessária segurança, a interpretação jurídica que prevalecerá no futuro sobre tomadas de posição que adotaram no presente.

Disso resulta a observação do juiz Sérgio Moro, expressada na introdução deste trabalho, quanto a ser ilegítima a atribuição de sanções a juízes e promotores que se posicionaram pela responsabilização dos acusados mas tiveram seus posicionamentos rejeitados no curso do processo, em "situação em que possivelmente podem sofrer acusações, não por terem agido abusivamente, mas, sim, porque adotaram uma interpretação que eventualmente não prevaleceu nas instâncias recursais ou superiores". Tecnicamente, juízes e promotores não 
podem ser responsabilizados na hipótese descrita por Moro porque não se configuram na espécie a voluntariedade da sua conduta e a sua culpabilidade. Afinal, se esses profissionais não tinham meios de antecipar qual interpretação prevaleceria ao fim do processo, não se pode, lucidamente, cogitar do seu livre propósito de descumprir o Direito (o que revela que a conduta não foi voluntária e nem dolosa) ou, quando menos, de negligência, imperícia ou imprudência de sua parte (o que afasta a configuração da culpa stricto sensu).

Esses elementos (exigência de voluntariedade da conduta e efetiva comprovação da culpabilidade) serão abordados nos tópicos que se seguem com o propósito de demonstrar que o raciocínio empregado por Moro naquela oportunidade também conduz à conclusão de que é ilegítima a atribuição a agentes estatais de sanções fundadas em simples "erro jurídico".

\section{Exigência de voluntariedade da conduta para incursão na infração}

A propósito, recordo que a Lei no 8.429/1992 (art. 11) admite a imputação de ato ímprobo a agentes estatais por contrariedade a princípios da Administração (entre eles o princípio da legalidade) e que é relativamente comum a sua integração ao polo passivo de processos em curso nos Tribunais de Contas, para que lhe sejam atribuídas sanções pessoais, quando se cogita da ilegalidade de atos por eles praticados. Essa responsabilização em tese pode recair quer sobre os advogados da Fazenda Pública, que detêm a atribuição constitucional de orientar a atividade administrativa, quer sobre os gestores/servidores que por eles são orientados na execução de suas tarefas. Posto isso, cumpre indagar se, dada a estrutura flexível da aplicação do Direito de nosso tempo, as condutas do advogado que profere parecer orientando a atividade administrativa e do gestor/servidor que, seguindo essa orientação jurídica, pratica atos concretos na execução da função administrativa comportam iniciativa voluntária desses agentes estatais por contrariar interpretações jurídicas divergentes manifestadas no futuro por órgãos de controle e pelo Poder Judiciário.

A mecânica dos opinamentos jurídicos e a responsabilização de procuradores por suas $\underline{\text { manifestações técnicas }}$

Na lição de Márcio Cammarosano, "o parecer jurídico [...] nada mais é do que um texto elaborado por profissional devidamente habilitado, consubstanciando seu entendimento a respeito de matérias ou questões jurídicas submetidas a sua apreciação" (1997). Conforme Cammarosano, "quem emite parecer jurídico está exercendo advocacia, quer se trate de jurista consagrado, atuando como profissional liberal, quer se trate de advogado titular de cargo público" (procuradores, consultores, assessores jurídicos, etc.); porque "descreve o direito, interpretando as normas jurídicas em geral, que entende pertinentes ao assunto submetido à sua apreciação"; atividade que, nos precisos termos da lei (Estatuto da Advocacia, art. 7º I c/c art. 31, p. 1º), deve ser 
exercida com liberdade (1997). O parecerista exerce, então, atividade normativa concreta correlata àquela desenvolvida pelos membros do Poder Judiciário, guardados, evidentemente, os escopos e eficácias peculiares de uma e outra atuação profissional ${ }^{4}$.

Em vista disso, Cammarosano (1997) observa que "a diferença fundamental entre o parecer e a decisão judicial é que esta decide a questão posta, é ato de aplicação da lei com força de coisa julgada”, ao passo que "aquele não decide nada", mas apenas "consubstancia a opinião jurídica de quem o subscreve, com vistas a orientar algum comportamento ou decisão". Porém, adverte o professor paulista, "tanto o juiz quanto o parecerista estão voltados ao conhecimento do direito, que pertence ao mundo das normas, susceptíveis não raras vezes de variadas interpretações, assim como podem variar os juízos de subsunção de um mesmo fato a esta ou àquela norma". Por isso é que as "decisões judiciais estão sujeitas a ser reformadas pelos Tribunais". Pela mesma razão, o parecer "pode receber a adesão de uns e não-acolhimento de outros". Ou seja, por mais sustentáveis que sejam as razões que embasam um parecer jurídico, não há garantias "de que o judiciário, se provocado, decidirá no mesmo sentido para o qual apontam".

O mesmo se verifica quando se tem em vista a atividade fiscalizatória exercida pelos Tribunais de Contas e por outros órgãos de controle (corregedorias, auditorias, etc.). Com efeito, como leciona Diogo de Figueiredo Moreira Neto, "não se questiona a competência das diversas Cortes de Contas do País de adotarem suas próprias interpretações do Direito", quer porque "o critério de juridicidade contido nos pareceres dos Advogados de Estado não se lhes obriga", quer porque esses pareceres "são apenas atos opinativos praticados sub censura, como, de resto, todos os atos interpretativos do Direito" (2009, p. 199). Enfim, "as Cortes de Contas, por se tratarem também de órgãos constitucionalmente independentes no desempenho de suas respectivas funções, [...] estão livres para adotar as interpretações que lhes pareçam mais adequadas", e por isso podem divergir, criticar e repudiar as conclusões de direito contidas em pareceres jurídicos (MOREIRA NETO, 2009, p. 199-200). Essas mesmas prerrogativas são extensíveis aos membros do Ministério Público, na medida em que sua competência constitucional para atuar na defesa dos interesses sociais (art. 127) confere-lhes a conotação de órgão externo de fiscalização e controle.

Mas isso não conduz, pelo menos não diretamente, à responsabilização dos advogados públicos que têm seus opinamentos criticados por controladores (inclusive promotores) e juízes; assim como, de igual modo, juízes

\footnotetext{
${ }^{4}$ Ao ensejo, José Joaquim Gomes Canotilho ensina que "para se passar da normatividade mediata para a normatividade concreta, a norma jurídica precisa de revestir o caráter da norma de decisão”, o que se faz por meio de processo de concretização normativa, que, para Canotilho, não se restringe ao campo do controle judicial (2000, p. 1.221). Conforme Canotilho, uma norma jurídica adquire verdadeira normatividade na medida em que a ordenação nela contida induza a decisão de um caso jurídico, isto é, quando o processo de concretização da norma se completa por meio da sua aplicação ao caso jurídico; o que pode se dar (i) pela criação de uma disciplina regulamentadora (concretização legislativa, regulamentar), no corpo de sentenças ou decisões judiciais (concretização judicial), e também através da prática de atos individuais por autoridades administrativas (concretização administrativa) (2000, p. 1.221).
} 
e promotores não devem ser responsabilizados quando, respectivamente, suas sentenças são reformadas pelos órgãos de jurisdição superior e suas denúncias/petições são rejeitadas pelo Poder Judiciário. Com efeito, a constatação de que a interpretação do Direito de nosso tempo pode resultar, conforme o intérprete, em diferentes soluções jurídicas para um mesmo problema, quando conjugada à circunstância de os juízes, quando se manifestam nos processos, atuarem no estrito cumprimento de um dever legal, conduziu à compreensão, encampada pelo artigo 49 da Lei Complementar no 35/1979 (Lei Orgânica da Magistratura Nacional) e pelo artigo 143 do Código de Processo Civil de 2015, segundo a qual esses profissionais apenas podem ser responsabilizados por suas manifestações jurídicas quando atuarem com dolo ou fraude, bem como quando recusarem, omitirem ou retardarem, sem justo motivo, providências que devam ordenar de ofício ou a requerimento das partes. Portanto, não se cogita, entre nós, da responsabilização de juízes por suas manifestações jurídicas, isto é, pela circunstância deles cometerem "erros de interpretação"; pois, do contrário, sempre que uma sentença judicial viesse a ser reformada, os magistrados estariam sujeitos a processos judiciais; o que certamente teria o condão de desestimular o exercício da função jurisdicional. Proteção semelhante é reconhecida pela doutrina aos membros do Ministério Público, com espeque no artigo 181 do Código de Processo Civil de 2015, que condiciona a sua responsabilização à depreensão de dolo ou fraude no exercício de suas atividades típicas (cf. NERY JUNIOR; NERY, 2006, p. 277). Assim não fosse, a simples rejeição de suas denúncias e petições poderia induzir a propositura de ações judiciais contra esses profissionais, desestimulando, de igual modo, o exercício de suas funções institucionais.

É certo que os precitados dispositivos legais, assim como a construção doutrinária que sobre eles se estabeleceu, referem-se à responsabilização de juízes e promotores em âmbito civil, com fundamento no parágrafo $6^{0}$ do artigo 37 da Constituição. No entanto, há quem defenda, em doutrina, a possibilidade da sua responsabilização por atos de improbidade administrativa, guardados, evidentemente, os devidos parâmetros legais (cf. OSÓRIO, 2008); pelo que não configura nenhum absurdo afirmá-los aplicáveis também ao campo da repressão jurídica ao ato ímprobo, situada no campo do Direito Administrativo Sancionador (cf. OSÓRIO, 2011). Disso se infere que, entre nós, juízes e promotores, porque se manifestam nos processos no estrito cumprimento de um dever legal, não podem ser pessoalmente condenados, em ações cíveis reparatórias ou de improbidade, pela tão-só circunstância de seus posicionamentos jurídicos não coincidirem com a interpretação prevalente por ocasião do desfecho do litígio perante os órgãos jurisdicionais. Em especial porque, dada a estrutura flexível do Direito de nosso tempo, esses profissionais têm dificuldades para antecipar, quando da formulação desses seus posicionamentos, qual interpretação jurídica prevalecerá ao final do processo.

Acredito que essa minha afirmação não causará espanto a quem quer que seja. O que é assombroso, dada a inequívoca estabilização dessa construção jurídica, é que, cotidianamente, integrantes do Ministério Público 
insistam em "denunciar" procuradores pela prática de atos de improbidade administrativa unicamente pela circunstância de os posicionamentos jurídicos por eles firmados não coincidirem com a sua interpretação pessoal (do promotor), ou com a interpretação manifestada por outros órgãos de controle (como, por exemplo, pelos Tribunais de Contas). Mas ainda mais alarmante é a constatação de que, em concreto, membros do Poder Judiciário (juízes, portanto) decidam pela sua condenação nos processos deflagrados, pela razão simples de (reitere-se) discordarem da interpretação por eles firmadas acerca de determinada questão jurídica. Como se fosse possível afirmar, em contradita à observação de Cammarosano (1997) e a tudo quanto restou assentado neste trabalho, que a possibilidade de divergência de entendimento entre profissionais igualmente sérios e competentes não é inafastável no mundo do Direito.

Não prospera, a propósito, o argumento segundo o qual juízes e promotores mereceram esse tratamento diferenciado porque o legislador os contemplou nos precitados dispositivos legais. É que o ordenamento confere, de igual modo, proteção jurídica às manifestações técnicas dos advogados, entre eles os advogados públicos. Com efeito, os procuradores, como advogados, são invioláveis por seus atos e manifestações no exercício da profissão, como se infere da leitura conjugada do artigo 133 da Constituição da República com o parágrafo $3^{\circ}$ do artigo $2^{\circ}$ da Lei no 8.906/1994 (Estatuto da Advocacia). Interpretando esses dispositivos, a Comissão Nacional da Advocacia Pública instituída no âmbito do Conselho Federal da Ordem dos Advogados do Brasil editou verbete de súmula que expressa que os advogados públicos, porque são invioláveis no exercício da função, não podem ser responsabilizados por suas opiniões jurídicas, ressalvada apenas a hipótese de dolo ou fraude (OAB/CNAP, Súmula no 6). Ou seja, na interpretação dada a esses dispositivos pela Ordem dos Advogados do Brasil, esses profissionais somente podem ser responsabilizados nas mesmas hipóteses em que o ordenamento admite a persecução contra juízes e promotores.

Semelhante opção normativa foi encampada pelo Código de Processo Civil de 1973 quando da edição da Lei no 10.358/2001 (que incluiu parágrafo único em seu artigo 14), e acabou mantida pelo código de 2015 (art. 77, IV e VI pp. $2^{\circ}$ e 6 ), que exclui os advogados públicos e privados (assim como os membros da Defensoria Pública e do Ministério Público) do rol de possíveis destinatários das multas aplicadas pelo legislador por ato atentatório à dignidade da justiça, sujeitando-os exclusivamente aos estatutos da Ordem dos Advogados do Brasil ${ }^{5}$. Desde logo observo que possíveis dúvidas quanto a aplicação do parágrafo único do artigo 14 do código de 1973 aos advogados públicos foram taxativamente dissipadas pelo Supremo Tribunal Federal quando do julgamento da Ação Direta de Inconstitucionalidade no 2.652, relatada pelo Ministro Maurício Correa. Na

\footnotetext{
${ }^{5}$ Essa orientação normativa resta assinalada, ainda, no seguinte verbete de súmula editado pela Comissão Nacional da Advocacia Pública do Conselho Federal da Ordem dos Advogados do Brasil: "Súmula 7 - Os Advogados Públicos, no exercício de suas atribuições, não podem ser presos ou responsabilizados pelo descumprimento de decisōes judiciais. A responsabilização dos gestores não pode ser confundida com a atividade de representação judicial e extrajudicial do advogado público".
} 
ocasião, o Tribunal Constitucional repudiou o estabelecimento de "discriminação em relação aos advogados vinculados a entes estatais", e por isso assentou, em interpretação conforme a Constituição, "que a ressalva contida na parte inicial desse artigo alcança todos os advogados, com esse título atuando em juízo, independentemente de estarem sujeitos também a outros regimes jurídicos". Esse posicionamento pretoriano foi incorporado ao texto do Código de Processo Civil de 2015, que dispõe, textualmente, que essas cominações não podem ser aplicadas "aos advogados públicos ou privados", enfatizando, ainda, que eventual responsabilidade desses profissionais deve "ser apurada pelo respectivo órgão de classe ou corregedoria, ao qual o juiz oficiará" (art. 77, p. $\left.6^{\circ}\right)^{6}$.

Essas disposições normativas, que há muito são aplicáveis ao exercício da advocacia, são até mais incisivas do que as que contemplam juízes e promotores, que apenas condicionam a sua responsabilização à depreensão de dolo ou fraude. Já aos advogados, inclusive aos advogados públicos, o ordenamento jurídicopositivo assegurou a sua inviolabilidade por atos e manifestações no exercício da profissão (CRFB, art. 133 c/c Lei nº 8.906/1994, art. $2^{\circ}$, p. $3^{\circ}$ ), que claramente alcança as suas manifestações jurídicas, prescrevendo, ainda, que essa sua atuação profissional nem sequer poderá ensejar a aplicação de multa pela prática de ato atentatório ao exercício da jurisdição (CPC-2015, art. 77, p. 60). Todavia, para que não restassem dúvidas quanto à ilegitimidade da responsabilização de procuradores por simples "erros jurídicos", o legislador processual expressou, no artigo 184 do Código de Processo Civil de 2015, que o membro da Advocacia Pública apenas pode ser responsabilizado quando agir com dolo ou fraude no exercício de suas funções.

A vinculação dos agentes estatais às interpretações firmadas pelas procuradorias como óbice conceitual à responsabilização de gestores e servidores que seguem suas orientações jurídicas

Dalmo de Abreu Dallari conceitua o Estado como "ordem jurídica soberana que tem por fim o bem comum de um povo situado em um território" (1998, p. 118). Ora, se o Estado, enquanto institucionalização política de uma sociedade, resulta de uma ordem jurídica, por óbvio não lhe assiste, sob qualquer perspectiva,

\footnotetext{
${ }^{6}$ Em vista dessas circunstâncias, Moreira Neto defende, em doutrina, que os advogados, entre eles os procuradores, somente podem ter as suas manifestações jurídicas questionadas perante a Ordem dos Advogados do Brasil. No pormenor, o publicista assevera que se assegura "ao Advogado de Estado, a inviolabilidade dos atos e manifestações no exercício da profissão", o "que faz de cada advogado um órgão unipessoal, intitulado ao exercício de uma parcela do poder estatal” e por isso "responsável único por seus atos e por suas manifestações jurídicas perante o seu órgão coletivo corporativo de controle para esse fim também elevado à in dependência constitucional - a Ordem dos Advogados do Brasil” (2009, p. 180). Disso decorre a seguinte conclusão, externada por esse professor fluminense na sequência: “[...] se a natureza opinativa das manifestações jurídicas - mesmo se vinculante na matéria de direito para o agente administrativo - é a que resulta do legítimo exercício da interpretação do Direito por parte do Advogado de Estado, a presunção de juridicidade, tanto de seu comportamento funcional, quanto de sua manifestação nesta qualidade, só pode ser afastada pelos órgãos constitucionalmente competentes para estabelecerem a culpa ou o dolo em sua atuação profissional e de, em consequência, a de lhes aplicar sanções em razão de um possível vicioso exercício profissional” (MOREIRA NETO, 2009, p. 187).
} 
desafiá-la. Destarte, a sua atuação frente à sociedade pressupõe atenção aos limites que the atribui essa mesma ordem jurídica. Afinal, como ensina Maria Sylvia Zanella Di Pietro, "a lei [...] estabelece também os limites da atuação administrativa que tenha por objeto a restrição ao exercício de [...] direitos em benefício da coletividade" (2001, p. 67).

Disso decorre a noção de legalidade, que, na feliz observação de Celso Antônio Bandeira de Mello, traduz o propósito político "de submeter os exercentes do poder em concreto - o administrativo - a um quadro normativo que embargue favoritismos, perseguições e desmandos" (2010.b, p. 100). Até porque, como lecionam Eduardo García de Enterría e Tomás-Ramón Fernández, "a legalidade a que a Administração está sujeita é antes de tudo uma técnica para garantir a liberdade", de tal sorte que "a violação à legalidade que leve o cidadão a suportar o que a lei não permite é uma agressão à sua liberdade e sua oposição a isto é uma defesa dela” (2008, p. 48).

Nessa senda, Bandeira de Mello acentua que "através da norma geral, abstrata e por isso mesmo impessoal", isto é, da "lei, editada, pois, pelo Poder Legislativo - que é o colégio representativo de todas as tendências (inclusive minoritárias) do corpo social", pretendeu-se "garantir que a atuação do Executivo nada mais seja senão a concretização dessa vontade geral" (2010.b, p. 100). Por esse motivo, os agentes estatais têm a sua atuação vinculada aos estritos limites do que lhes determinam a lei e a Constituição. Cumpre-lhes, pois, em suas atividades cotidianas, aplicar corretamente o Direito, servindo, assim, aos interesses juridicizados pelos legítimos representantes do povo.

Orienta, de igual modo, a vinculação dos agentes estatais a uma correta aplicação do Direito, a necessidade que tem a Administração Pública de promover a realização do interesse público. A propósito, Bandeira de Mello expressa que "a noção de interesse púbico [...] impede que se incida no equívoco muito grave de supor que o interesse púbico é exclusivamente um interesse do Estado", lapso de compreensão "que faz resvalar fácil e naturalmente para a concepção simplista e perigosa de identificá-lo com quaisquer interesses da entidade que representa o todo" (2010.a, p. 187; 2010.b, p. 65). Para esse professor paulista "o Estado, tal como os demais particulares, é, também ele, uma pessoa jurídica, que, pois, existe e convive no universo jurídico em concorrência com todos os demais sujeitos de direito", e que, por isso, "independentemente do fato de ser, por definição, encarregado de interesses públicos", pode ter, como qualquer outra pessoa, "interesses que the são particulares, individuais, e que, tal como os interesses delas, concebidas em suas meras individualidades, se encarnam no Estado enquanto pessoa" (2010.a, p. 188; 2010.b, p. 65-66). Esses últimos interesses não são, conforme Bandeira de Mello, "interesses públicos", mas se qualificam, na verdade, como "interesses individuais do Estado" (2010.a, p. 
188 $)^{7}$ (por exemplo, cobrar tributos). Esses interesses particulares do Estado só merecem proteção jurídica quando instrumentais ao interesse público (2010.a, p. 188) (por exemplo, cobrar tributos dentro dos limites legais, para tornar viável o fornecimento de serviços públicos). Por isso é que, na acepção teórica adotada por Bandeira de Mello, o interesse público consiste no interesse do Estado e da sociedade na observância da ordem jurídica estabelecida (2010.b, p. 62), pressupondo, assim, uma correta aplicação do Direito (MADUREIRA, 2015, p. 52-58; MADUREIRA, 2011).

Mas em que consiste, dada a possibilidade da configuração de interpretações divergentes no campo da aplicação do Direito, a sua correta aplicação? A resposta a esse questionamento não é automática, pois, dada a estrutura flexível do Direito de nosso tempo, pode haver divergências de interpretação na esfera administrativa.

Essas divergências, entretanto, são solucionadas por mecanismo concebido pela Constituição da República, quando conferiu à Advocacia Pública, em seus artigos 131 e 132, as atividades de consultoria jurídica e de contencioso judicial. A atividade consultiva destina-se à orientação dos agentes estatais sobre como deve se dar a aplicação do Direito ${ }^{8}$. No contencioso judicial, por sua vez, os advogados públicos atuam como partícipes da atividade cognitiva desenvolvida pela comunidade de intérpretes com vistas à interpretação e aplicação do Direito (cf. MADUREIRA, 2013, p. 117-268), com a missão de procurar convencer o Poder Judiciário de que as posturas defendidas pela Administração Pública encontram amparo no ordenamento jurídico-positivo. Em uma e outra esfera, podem ser depreendidos equívocos na aplicação do Direito pela Administração Pública, preordenados, sobretudo, pela circunstância de nem todos os agentes estatais haverem sido formados para aplicar as regras e princípios que compõem o ordenamento. Destarte, quer quando exercem a consultoria jurídica, quer quando atuem no contencioso judicial, os advogados públicos devem orientar os governantes e demais agentes estatais para que suas ações sejam lícitas, recomendando a correção de possíveis equívocos jurídicos cometidos no exercício da função administrativa, e exercendo, assim, o que em doutrina se convencionou chamar controle interno da juridicidade do agir administrativo (cf. MADUREIRA, 2015, p. 102-106). Opera-se, assim, por meio da Advocacia Pública, a uniformização da interpretação e aplicação do Direito pela Administração (cf. MADUREIRA, 2015, p. 243-248).

Esses pressupostos teóricos (adstrição da Administração e seus agentes à legalidade administrativa e à necessidade de realização do interesse público) conferem relativa vinculatividade aos posicionamentos jurídicos firmados pelas procuradorias. O que ocorre é que, muito embora os governantes e demais autoridades

\footnotetext{
${ }^{7}$ Esses interesses designados por Bandeira de Mello como "interesses individuais do Estado" correspondem aos "interesses secundários" referidos por Alessi, ao passo que a "dimensão pública desses interesses individuais”, que o professor paulista qualifica como "interesse público", corresponde ao que Alessi convencionou chamar "interesse primário" (ALESSI, 1960. p. 197).

${ }^{8}$ Afinal, como leciona o Professor Ricardo Marcondes Martins, "o Estado de Direito [...] veda o arbítrio dos agentes públicos", vinculando a atuação estatal à aplicação de normas jurídicas, o que faz com que, em concreto, o exercício da função pública
} 
administrativas em princípio somente estejam obrigados a aderir às orientações jurídicas dos procuradores nas hipóteses em que a lei considera vinculantes os pareceres por eles exarados, a circunstância de a Constituição (arts. 131 e 132) haver conferido a esses profissionais orientar a aplicação do Direito em sede administrativa impõe aos orientados, como regra geral, o atendimento às recomendações da procuradoria. Quanto deixam de observá-las, gestores e servidores, porque confrontados com a opinião jurídica do órgão que detém a atribuição constitucional de uniformizar a aplicação do Direito na esfera administrativa, assumem o risco de praticar conduta ilegal em ofensa ao princípio administrativo da legalidade, e, o que é pior, o fazem cientes de que podem estar praticando uma ilegalidade, violando, assim, também o princípio da moralidade administrativa (cf. MADUREIRA, 2015, p. 331-333).

Márcio Cammarosano explicita essa particularidade do agir administrativo por meio de um exemplo prático, quando refere à postura de administrador municipal que formula determinada exigência a proprietários de bens imóveis, e que, constatando, adiante, após ouvir a procuradoria, que tal providência, por exigência do Direito, não poderia ser imposta a todos os proprietários, persiste no seu propósito de exigir-lhes a prestação, à consideração de que "a maioria dos notificados, pelas mais variadas razões, dentre elas a desinformação, contra as notificações indevidas não se insurgem, e até apressam-se em cumprir o que se lhes determina, ou acabam por pagar a multa aplicada" (2006, p. 103-104). Referindo-se a essa hipótese fática, Cammarosano expressa que "à invalidade dos atos expedidos - porque em descompasso com a lei - soma-se, é certo, vício de ordem moral [...]”, pois há "violação também do princípio da finalidade do interesse público, com a qual não se compadece a consciente violação da lei; a violação do princípio jurídico da boa-fé; a violação, enfim, da moralidade administrativa" (2006, p. 104-105).

Se, por qualquer motivo, pretenderem inobservar as recomendações da procuradoria, cumpre aos orientados manifestar, em cada caso concreto, as razões jurídicas em que se funda a sua divergência com a orientação desatendida. Por óbvio, não se prestam a tanto a invocação de argumentos externos ao Direito, como ocorre, por exemplo, quando se afirma, com esse intuito, que a adoção do referido opinamento contraria "razões superiores de Estado", ou o "bem maior", ou, ainda, uma acepção distorcida de “interesse público", para esse efeito erroneamente compreendido como interesse do Governo ou do poder público. Cuidando-se o parecer desatendido de uma manifestação técnica, fundada em razões intrínsecas ao conhecimento jurídico, apenas argumentos de idêntica natureza legitimam a conduta dos orientados que pretenderem deixar de observá-lo. $\mathrm{Na}$ impossibilidade de articulá-los, os orientados, se persistirem em seu propósito de desatender a orientação firmada no parecer, deverão solicitar uma nova manifestação da procuradoria, contexto em que a invocação de "razões

pressuponha a concretização do ordenamento posto por esses agentes estatais (MARTINS, 2011, p. 141-142). Sobre o assunto, cf., também: MARTINS, 2008. p. 64-102. 
superiores de Estado" (ou de qualquer de seus equivalentes semânticos) poderá, inclusive, conforme o caso, justificar uma modificação do posicionamento anteriormente enunciado, por exemplo quando se verificar, em vista de novos elementos fáticos apresentados, que a implementação da solução proposta no parecer mostra-se ofensiva ao princípio administrativo da eficiência, ou, talvez, à própria segurança jurídica. Porém, mantendo-se os orientados inertes quanto ao cumprimento do parecer e silentes quanto às razões porque discordam das orientações jurídicas nele contidas, ter-se-á, em concreto, inequívoca inobservância ao Direito, tal como interpretado pela procuradoria, a ensejar, na prática, ofensa aos princípios administrativos da legalidade e da moralidade. E isso porque, na hipótese, gestores/servidores, sem sequer esboçar interpretação jurídica que em tese refute a juridicidade do parecer descumprido, estariam se recusando a adequar sua conduta ao ordenamento jurídico-positivo, praticando, assim, uma ilegalidade; atitude que, conjugada à circunstância de terem sido previamente cientificadas pela procuradoria da ilegitimidade do ato praticado, induz, ademais, infração aos princípios jurídicos da finalidade do interesse público, da boa-fé e, por conseguinte, da moralidade administrativa.

A inobservância desses cuidados pode, inclusive, induzir a responsabilização dos orientados por ato de improbidade administrativa, por violação a princípios da Administração Pública (Lei no 9.429/1992, art. 11), mais especificamente aos princípios da legalidade e da moralidade (CRFB, art. 37, caput $)^{9}$, assim como a sua identificação no polo passivo de processos abertos pelos Tribunais de Contas para investigar a ilegalidade do ato praticado. Posto isso, não é esperado que gestores e servidores deixem de seguir as orientaçóes jurídicas das procuradorias. A regra geral, nesse contexto, será o atendimento às recomendaçóes formuladas pelos procuradores.

Sendo assim, o raciocínio segundo o qual os advogados públicos não podem sofrer sanções quando se verificar, nos casos concretos, que as interpretações jurídicas por eles veiculadas não coincidiram com os posicionamentos ulteriores dos órgãos de controle e do Poder Judiciário, precisa ser estendido, por similaridade de premissas, aos gestores e servidores que atenderem suas orientações. Do contrário, estar-se-ia a admitir tratamento discriminatório entre agentes estatais, em clara violação ao princípio constitucional da isonomia (CRFB, art. 5o, caput). Destarte, deve estar claro que, como os procuradores que orientam a aplicação do Direito pela Administração, também os gestores/servidores que praticam atos concretos atendendo orientação jurídica fundada em interpretação posteriormente rechaçada pelos órgãos de controle e pelo Poder Judiciário não o fazem com o ânimo de descumprir o Direito. Afinal, esses gestores/servidores, que muitas vezes sequer possuem formação jurídica, têm ainda menos condições que os procuradores de antecipar os posicionamentos que serão

\footnotetext{
${ }^{9}$ É certo que, na espécie, a validade da imputação pressupõe conduta dolosa do agente imputado. No entanto, uma vez apontada a ilegitimidade do ato, a tão-só insistência do agente estatal em manter-lhe os efeitos a despeito dos vícios jurídicos que lhe foram apontados pela procuradoria, conjugada à sua inércia em fundamentar, sob bases jurídicas, as razões de seu convencimento, em tese
} 


\section{manifestados no futuro por controladores e juízes.}

\section{Exigência de voluntariedade da conduta como resultado da predeterminação formal do Direito}

A impossibilidade material de que os agentes estatais antecipem, com a necessária certeza, como se manifestarão no futuro os órgãos de controle e o Poder Judiciário, obstam, em absoluto, a sua responsabilização sob a invocação de simples equívoco jurídico. É que, na hipótese, está ausente, indubitavelmente, requisito indispensável à coercibilidade do Direito, consistente na sua predeterminação formal.

Essa é, na verdade, uma exigência da Teoria Geral do Direito, há muito expressada por Miguel Reale (1992, p. 273), que tem por finalidade assegurar a necessária segurança nas relações interpessoais. Reale observa, a propósito, que, "de todas as espécies de experiência social, o Direito é a que mais exige forma predeterminada e certa em suas regras" (1992, p. 273). Para esse professor paulista, "não se compreende o Direito [...] sem um mínimo de legislação escrita, de certeza, de tipificação da conduta e de previsibilidade genérica", precisamente porque "o Direito, ao facultar-lhe a possibilidade de escolha entre o adimplemento ou não dos seus preceitos, situa o obrigado no âmbito de uma escolha já objetivamente feita pela sociedade, escolha esta revelada através de um complexo sistema de fontes" (REALE, 1992, p. 273). Daí que, conforme Reale, "o Direito [...] exige predeterminação formal, sendo a lei a expressão máxima dessa exigência” (1992, p. 273) ${ }^{10}$.

Posto isso, configura-se, na espécie, o que Celso Antônio Bandeira de Mello convencionou chamar "princípio da exigência de voluntariedade para incursão na infração" (2010.b, p. 855). Quanto ao particular, Bandeira de Mello observa que "o Direito propõe-se a oferecer às pessoas uma garantia de segurança, assentada na previsibilidade de que certas condutas podem ou devem ser praticadas e suscitam dados efeitos", enquanto "outras não podem sê-lo, acarretando consequências diversas, gravosas para quem nelas incorrer” (2010.b, p. 855). Disso decorre, para o publicista, a impropriedade da qualificação de "alguém como incurso em infração quando inexista a possibilidade de prévia ciência e prévia eleição, in concreto, do comportamento que o livraria da incidência na infração e, pois, na sujeição às sanções para tal caso previstas" (MELLO, 2010.b, p. 855). Essa compreensão, que, para Bandeira de Mello, é externa a considerações sobre a culpabilidade do agente (investigação de dolo ou culpa), vez que incide "meramente no animus de praticar dada conduta" (2010.b, p. 855), é argumento suficiente ao afastamento da responsabilização de agentes estatais quando se está diante tão-somente de divergência entre o posicionamento jurídico que embasa a prática do ato questionado e as manifestações ulteriores dos órgãos de controle e do Poder Judiciário.

denota o seu livre propósito (atitude dolosa, portanto) de contrariar o Direito pátrio. Trata-se, pois, de assunto que ultrapassa o âmbito das indagações formuladas neste trabalho, pelo que me reservo a enfrentá-lo em estudo específico. 


\section{Exigência da efetiva demonstração da culpabilidade do agente imputado}

A circunstância, retratada no tópico anterior, de os agentes estatais não disporem de meios materiais de antecipar com a necessária segurança o posicionamento que será ulteriormente manifestado pelos órgãos de controle e pelo Poder Judiciário também afeta a demonstração da sua culpabilidade. Como cediço, entre nós é requisito indispensável à responsabilização dos agentes imputados a efetiva demonstração da sua culpabilidade (cf. OLIVEIRA, 2009, p. 215). Incide, pois, na espécie, a responsabilização subjetiva dos agentes imputados, justificada por José Roberto Pimenta Oliveira a partir das seguintes considerações doutrinárias:

[...] O Estado Democrático de Direito tem, em seu epicentro axiológico, a dignidade da pessoa humana (art. 10, III), que implica no direito fundamental de inviolabilidade à liberdade e à propriedade (art. $5^{\circ}$, caput). Como derivação surge a consagração da vedação constitucional de privação da liberdade e de bens sem o devido processo legal (art. 5\%, LIV). Densificando, na própria esfera constitucional, esta magna garantia fundamental, contemplase o princípio da individualização das sanções (art. $\left.5^{\circ}, \mathrm{XLVI}\right)$, quando o Estado opera em sua atividade punitiva.

O resultado desta teia principiológica e fruto de conquista civilizatória na limitação dos poderes estatais desemboca na afirmação da normatividade do princípio da culpabilidade, imponível como condição constitucional de legitimação para edição de qualquer medida sancionatória por órgão ou estatal. (2009, p. 215)

Nesse mesmo sentido é o posicionamento consolidado pelos Tribunais brasileiros, sob a liderança do Superior Tribunal de Justiça, Corte a quem a Carta da República atribui competência para a uniformização da jurisprudência no que se refere à interpretação e aplicação do direito federal. A propósito, reporto-me, exemplificativamente, ao julgamento do Recurso Especial no 751.634, relatado pelo Ministro Teori Zavascki, no corpo do qual a Corte Superior de Justiça assentou que "em atenção ao princípio da culpabilidade e ao da responsabilidade subjetiva, não se tolera responsabilização objetiva" ${ }^{11}$.

Posto isso, não se justifica, entre nós, a responsabilização de agentes estatais pela tão-só circunstância de controladores (inclusive promotores) e juízes discordarem de seus posicionamentos jurídicos (procuradores) ou dos posicionamentos jurídicos que orientaram a sua atuação (servidores/gestores); dada a absoluta necessidade de se demonstrar, em concreto, que esses profissionais se preordenaram deliberadamente (portando, mediante conduta dolosa) a contrariar o Direito ${ }^{12}$, ou, quando menos, que assim se manifestaram mediante culpa grave, que

\footnotetext{
${ }^{10}$ Sobre a exigência de predeterminação formal das normas jurídicas, cf., ainda: CAMMAROSANO, 2006, p. 42 e 63-64.

${ }^{11}$ Cf. STJ, REsp 751.634, Relator Ministro Teori Albino Zavascki. Nesse mesmo sentido decidiu a Corte Superior de Justiça quando da apreciação dos Recursos Especiais no 805.080 e 875.163, ambos relatados pela Ministra Denise Arruda.

${ }^{12}$ No ponto, é importante acrescentar que a jurisprudência do Superior Tribunal de Justiça condiciona a responsabilização à demonstração do dolo da conduta (arts. $9^{\circ}$ e 11) ou, quando menos, de culpa grave (cf. REsp 805.080, Relatora Ministra Denise Arruda; REsp 751.634, Relator Ministro Teori Albino Zavascki; AgRg no AREsp 73968, Relator Ministro Benedito Gonçalves; REsp 1130584, Relator Ministro Teori Albino Zavascki; AgRg no AREsp 184147, Relator Ministro Humberto Martins; AgRg no REsp 1253667, Ministro Humberto Martins; AgRg no REsp 975540/SP, Relator Ministro Teori Albino Zavascki) e que o Código de Processo Civil de 2015, editado posteriormente à formação desses precentes, estabelece, textualmente, que "o membro da Advocacia Pública será civil e regressivamente responsável quando agir com dolo ou fraude no exercício de suas funções” (art. 184).
} 
pressupõe a depreensão de erro grosseiro ${ }^{13}$, revelador da sua negligência, imperícia ou imprudência quando da formulação/acatamento da interpretação jurídica questionada.

Destarte, não é suficiente à responsabilização, seja dos procuradores que orientam, sob o ponto de vista jurídico, o agir administrativo, seja dos gestores e servidores por eles orientados, a tão só afirmação da ilegalidade do ato questionado. Nesse sentido se posicionou o Superior Tribunal de Justiça no contexto do julgamento da Ação de Improbidade Administrativa no 30, também relatada pelo Ministro Teori Zavascki, quando assentou (i) que "não se pode confundir improbidade com simples ilegalidade", (ii) que "a improbidade é ilegalidade tipificada e qualificada pelo elemento subjetivo da conduta do agente", (iii) que "a jurisprudência do STJ considera indispensável, para a caracterização de improbidade, que a conduta do agente seja dolosa, para a tipificação das condutas descritas nos artigos 9० e 11 da Lei 8.429/92, ou pelo menos eivada de culpa grave, nas do artigo 10". Esse posicionamento firmado pelo Ministro Zavascki foi reproduzido, adiante, em diversos outros julgamentos, que encartam a jurisprudência consolidada naquela Corte Superior de Justiçą ${ }^{14}$.

É indubitável que não atua com dolo ou culpa grave o profissional que, manifestando-se fundamentadamente, expressa simples opinião jurídica sobre temas que compõem o objeto de consulta que the foi submetida. Assim se manifestou a Corte Superior de Justiça, em outra decisão paradigmática, proferida quando do julgamento do Recurso Especial no 1.183.504, relatado pelo Ministro Humberto Martins. Na ocasião, conquanto tenha admitido ser viável, "em situações excepcionais, enquadrar o consultor jurídico ou o parecerista como sujeito passivo numa ação de improbidade administrativa”, o Tribunal advertiu que, para tanto, é preciso que a peça opinativa se apresente como "um instrumento, dolosamente elaborado, destinado a possibilitar a realização do ato ímprobo", dispondo, em arremate, que é "necessário, para que se configure essa situação excepcional, que desde o nascedouro a má-fé tenha sido o elemento subjetivo condutor da realização do parecer".

Também não se pode atribuir má-fé aos gestores/servidores que praticam atos concretos em atenção a orientações jurídicas da procuradoria. Com efeito, detendo a procuradoria competência constitucional (arts. 131 e 132) para uniformizar a aplicação do Direito da esfera administrativa, o que faz com que as suas manifestações se apresentem, para a Administração, como representação concreta da ideia de legalidade, não se cogita de dolo ou culpa na conduta dos agentes estatais que seguem essas suas orientações jurídicas. Destarte, aplica-se a eles a mesma construção teórica e os mesmos precedentes que conduzem, pelas razões dantes expostas, ao afastamento da culpabilidade dos procuradores.

\footnotetext{
${ }^{13}$ Quanto ao particular, cf. STF, MS 24631/DF, Relator Ministro Joaquim Barbosa, Julgamento: 09/08/2007, Tribunal Pleno, Publicação DJe-018 DIVULG 31-01-2008 PUBLIC 01-02-2008.
} 


\section{CONCLUSÕES}

Espero haver demonstrado que o Direito de nosso tempo, em especial no regime jurídico brasileiro, é de tal forma flexível que não é razoável supor que, no campo de sua aplicação, os intérpretes/aplicadores tenham meios de antecipar, com a necessária segurança, a interpretação jurídica que prevalecerá, no futuro, sobre a validade de atos praticados a partir das orientações jurídicas firmadas no âmbito da Administração Pública. Qualquer tentativa de responsabilizá-los, como se verifica na situação levantada pelo juiz Sérgio Moro na entrevista mencionada na introdução deste trabalho, traduz, em rigor, lamentável reinvenção dos ilícitos de hermenêutica ${ }^{15}$.

Se o Direito de nosso tempo é flexível a ponto de em geral não permitir a configuração de uma única resposta correta para a resolução dos problemas jurídicos que despontam nos casos concretos, é imperativo que os intérpretes tomem as precauções necessárias a que não seja inadvertidamente responsabilizado aquele que produziu resposta jurídica não coincidente com a resposta final (ou oficial) sobre como deve se dar a aplicação do Direito à hipótese analisada mas que ainda assim representa aplicação possível à luz das balizas normativas e axiológicas postas pelo ordenamento. A ser de outro modo, estar-se-ia colocando os intérpretes, nas palavras de Sérgio Moro (que foram dirigidas especificamente à atuação de juízes e promotores, mas que se aplicam, por similaridade de premissas, a todo e qualquer aplicador do Direito), "numa situação em que possivelmente podem sofrer acusações, não por terem agido abusivamente, mas, sim, porque adotaram uma interpretação que eventualmente não prevaleceu nas instâncias recursais ou superiores".

Quando se tem em vista a atuação da Administração Pública o problema se torna ainda mais agudo. É que, nesse campo, para além de ser imprópria, pelas razões dantes expostas, a aplicação de sanções fundadas em simples divergências de interpretação é também indesejável (e por isso mesmo é ilegítima), porque põe em risco o adequado funcionamento das instituições democráticas.

Quando abordei, tópicos atrás, o tratamento normativo conferido pelo ordenamento jurídico-positivo a juízes e promotores no que se refere aos limites de sua responsabilização pessoal por erros de interpretação ${ }^{16}$, aludi

\footnotetext{
${ }^{14}$ Cf. AgRg no AREsp 73968, Relator Ministro Benedito Gonçalves; REsp 1130584, Relator Ministro Teori Albino Zavascki; AgRg no AREsp 184147, Relator Ministro Humberto Martins; AgRg no REsp 1253667, Ministro Humberto Martins; AgRg no REsp 975540/SP, Relator Ministro Teori Albino Zavascki.

${ }^{15}$ Há muito denunciados por Rui Barbosa, quando criticava a responsabilização de magistrados pela tão só circunstância de aplicarem a lei de forma dissonante com o entendimento prevalente sobre a resolução de questões por eles decididas. Em suas próprias palavras: "Para fazer do magistrado uma impotência equivalente, criaram a novidade da doutrina, que inventou para o juiz os crimes de hermenêutica, responsabilizando-o penalmente pelas rebeldias da sua consciência ao padrão oficial no entendimento dos textos. Esta hipérbole do absurdo não tem linhagem conhecida: nasceu entre nós por geração espontânea. E, se passar, fará da toga a mais humilde das profissões servis, estabelecendo, para o aplicador judicial das leis, uma subalternidade constantemente ameaçada pelos oráculos da ortodoxia cortesã” (BARBOSA, 1991, p. 246).

${ }^{16}$ Vide LC 35, art. 49 c/c CPC-2015, art. 143 (no que se refere à responsabilização dos juízes) e CPC-2015, art. 181 (no que se refere à responsabilização dos promotores).
} 
ao risco de que, se essas limitações não estivessem postas, sempre que suas manifestações não fossem confirmadas no curso do processos (o que é bastante comum na prática jurídica) seus prolatores estariam sujeitos a processos judiciais, com inegável desestímulo ao exercício de suas atribuições profissionais. Precisamente por esse motivo o Direito Brasileiro conferiu proteção semelhante aos advogados públicos, que mereceram do legislador o reconhecimento da sua inviolabilidade por atos e manifestações no exercício da profissão (CRFB, art. 133 e Lei no 8.906/1994, art. 2º p. 3º), além da previsão, colhida do artigo 184 do Código de Processo Civil, quanto a somente poderem vir a ser responsabilizados, no exercício de suas funções, quando agirem com dolo ou fraude no exercício de suas funções. Mesmo assim, ainda é bastante comum a imputação de sanções a esses profissionais sob a exclusiva invocação da circunstância de seus posicionamentos jurídicos não coincidirem com a interpretação ulteriormente firmada por controladores e juízes. Essas iniciativas, que por vezes redundam na condenação do advogado, além de não corporificarem, na linha do que se demonstrou anteriormente, uma correta aplicação do Direito, induzem, em concreto, sério desestimulo ao exercício da Advocacia Pública e ao ingresso/manutenção de bons profissionais em seus quadros ${ }^{17}$.

Essa proteção jurídica precisa ser estendida aos demais agentes estatais. Ainda que o legislador não a tenha conferido de forma expressa a gestores e servidores, a circunstância de a sua atuação pressupor uma correta aplicação do Direito (dada a incidência do princípio administrativo da legalidade e de uma adequada conceituação do interesse público), quando conjugada à constatação de que o Direito de nosso tempo é flexível, não admitindo, pelas razões dantes expostas, uma única resposta correta, e de que a sua atuação em geral é orientada, sob os aspectos jurídicos, por interpretações uniformizadoras construídas no âmbito da Advocacia Pública, exige que lhes seja conferido idêntico tratamento.

Esse é um tema que certamente merece uma reflexão da comunidade jurídica. Com efeito, a pretexto de combater a corrupção (iniciativa absolutamente desejável e merecedora de aplausos), controladores e juízes irrefletidamente procuram responsabilizar profissionais sérios, que, fazendo o seu trabalho, apenas se conduziram com base em interpretações jurídicas que adiante foram consideradas equivocadas pelos órgãos de controle e pelo Poder Judiciário. Quando isso acontece, esses profissionais são obrigados a contratar advogados para se defender e se veem obrigados a suportar, por anos a fio, as consequências de terem deflagrados contra si processos que apontam supostas irregularidades em sua conduta no exercício da função administrativa, com todas as repercussões que semelhante persecução jurídica pode trazer à honra de uma pessoa e ao seu convívio social. Esse tipo de iniciativa, para além de não atingir os corruptos, que custearão os honorários de seus advogados com o

\footnotetext{
${ }^{17}$ Ao ensejo, recobro a advertência de Diogo de Figueiredo Moreira Neto quando acentua que a manutenção desses equívocos "ao revés de concorrer para o aperfeiçoamento da Administração, desestimulará uma geração de jovens advogados de Estado concursados", que certamente temem as "consequências que possam decorrer do exercício independente e intimorato de sua
} 
proveito econômico de suas manobras administrativas e que em geral não se abalam com acusações dessa natureza, culmina por desestimular que pessoas honestas e preocupadas com o seu bom nome venham trabalhar na Administração Pública. Enfim, se não soubermos separar o joio do trigo, corremos o risco de que os esforços de controladores e juízes em vez de inibir a corrupção sirvam-lhe de estímulo.

Não discordo da responsabilização de agentes estatais quando suas posturas se contaminam por vícios de outra natureza, como ocorre, por exemplo, quando se verifica o recebimento de vantagem financeira para proferir pareceres que orientem condutas contrárias ao Direito, ou para praticar atos que se sabe ilegais. O que me causa apreensão, como intérprete, como estudioso do Direito e, sobretudo, como cidadão, é que se afirme, muitas vezes com naturalidade, ser viável, à luz do ordenamento jurídico-positivo, a aplicação de sanções a procuradores e gestores/servidores pela tão-só circunstância deles não terem conseguido antecipar, respectivamente, quando da formulação de suas manifestações jurídicas e da implementação prática desses opinamentos, os posicionamentos ulteriormente firmados pelos órgãos de controle e pelo Poder Judiciário.

\title{
ILLEGITIMITY OF THE APPLICATION TO STATE AGENTS OF SANCTIONS FOUNDED IN SIMPLE "LEGAL ERROR"
}

\begin{abstract}
The objective of this article is to demonstrate that the flexible structure of the Law of our time make it impossible for State officials to be liable for sanctions which arise from a simple divergence in the interpretation of legal texts ("legal error"). To achieve it, I start from the premise that the law applied to concrete cases is reconstructed by the interpreters in the field of its application, resulting from the decline of the liberal-bourgeois normative paradigm, in a profound change in the way in which legislative texts were produced, which began to employ general clauses and indeterminate legal concepts, the rise of constitutional jurisdiction as a method of controlling the rationality and the justice of legislative acts and the theoretical confirmation that the incidence, in view of these assumptions, a single correct answer to the settlement of disputes does. This peculiarity in the application of the Law prevents state agents from anticipating, with necessary security, the juridical interpretation subsequently manifested by the control organs and by the Judiciary, refuting the simplicity of the characterization of the voluntariness of their conduct and the demonstration of their guilt, of the possibility of being awarded sanctions based on "legal errors".
\end{abstract}

Keywords: Right; Hermeneutics; Legal Error; State agents; Penalties.

\section{REFERENCIAS BIBLIOGRÁFICAS}

ALESSI, Renato. Sistema instituzionale Del Diritto Amministrativo Italiano. 3 ed. Milão: Giuffrè Editore, 1960.

profissão, ante a possibilidade de serem acoimados de faltosos e de receberem sanções pecuniárias" unicamente porque seus opinamentos jurídicos não coincidem com a interpretação posteriormente manifestada pelos órgãos fiscalizatórios (2009, p. 195). 
ALEXY, Robert. Constitucionalismo discursivo. Tradução de Luís Afonso Heck. Porto Alegre: Livraria do Advogado, 2007.

"Ponderação, jurisdição constitucional e representação". In.: ALEXY, Robert. Constitucionalismo discursivo. Tradução de Luís Afonso Heck. Porto Alegre: Livraria do Advogado, 2007.

ÁVILA, Humberto. Teoria dos princípios: da definição à aplicação dos princípios jurídicos. 4. ed. São Paulo: Malheiros, 2005.

BARBOSA, Rui. O júri e a independência da magistratura. In.: BARBOSA, Rui. Obras completas, Volume 23, Tomo III. Rio de Janeiro: Fundação Casa de Rui Barbosa, 1991. Disponível na internet: <http://www.stf.jus.br/bibliotecadigital/ruibarbosa/18428/pdf/18428.pdf>; acesso em 23/05/2017.

Obras completas, Volume 23, Tomo III. Rio de Janeiro: Fundação Casa de Rui Barbosa, 1991. Disponível na internet: <http://www.stf.jus.br/bibliotecadigital/ruibarbosa/18428/pdf/18428.pdf>; acesso em 23/05/2017.

BOBBIO, Norberto. O positivismo jurídico: lições de filosofia do direito. Tradução e notas de Márcio Pugliese, Edson Bini, Carlos E. Rodrigues. São Paulo: Ícone, 1995.

BONAVIDES, Paulo. Do Estado liberal ao Estado social. 8. ed. São Paulo: Malheiros, 2007.

CAMMAROSANO, Márcio. Da responsabilidade de autoridades por atos que expedem tendo por suporte pareceres jurídicos, e dos autores destes. Informativo de Licitações e Contratos, ano 4, n. 37, mar. 1997.

2006.

O princípio constitucional na moralidade e o exercício da função administrativa. Belo Horizonte: Fórum,

CANOTILHO, José Joaquim Gomes. Direito Constitucional e Teoria da Constituição. 7. ed. Coimbra: Almedina, 2000.

CARVALHO, Paulo de Barros. Curso de Direito tributário. 9. ed. São Paulo: Saraiva, 1997.

DALLARI, Dalmo de Abreu. Elementos de Teoria Geral do Estado. 20. ed. São Paulo: Saraiva, 1998.

DI PIETRO, Maria Sylvia Zanella. Direito Administrativo. 13. ed. São Paulo: Atlas, 2001.

DIDIER JÚNIOR, Fredie; MAZZEI, Rodrigo Reis [Coord.]. Reflexos do Novo Código Civil no Direito Processual. Salvador: Juspodivm, 2006.

DWORKIN, Ronald. Levando os direitos a sério. Tradução de Nelson Boeira. São Paulo: Martins Fontes, 2002.

ENTERRÍA, Eduardo García de; FERNÁNDEZ, Tomás-Ramón. Curso de Derecho Administrativo, vol. II. 11. ed. Madri, Thomson Civitas, 2008.

GADAMER, Hans-Georg. Verdade e método: traços fundamentais de uma hermenêutica filosófica, v. 1. Tradução Flávio Paulo Meurer e revisão de Ênio Paulo Giachini. 4. ed. Petrópolis: Vozes, 2000.

GRAU, Eros Roberto. Ensaio e discurso sobre a interpretação/aplicação do direito. 3. ed. São Paulo: Malheiros, 2005. 
HABERMAS, Jürgen. Direito e democracia entre facticidade e validade - Volume II. Tradução de Flávio Beno Siebeneichler. Rio de Janeiro: Tempo Brasileiro, 2003.

HART, Herbet L. A. O conceito de Direito. 3. ed. Tradução de A. Ribeiro Mendes. Lisboa: Fundação Calouste Gulbenkian, 1994.

KELSEN, Hans. Teoria Pura do Direito. 7. ed. São Paulo: Martins Fontes, 2006.

LIMA NETO, Francisco Vieira. O Direito de não sofrer discriminação genética: uma nova expressão dos direitos da personalidade. Rio de Janeiro: Lumen Juris, 2008.

MADUREIRA, Claudio. A mecânica dos opinamentos jurídicos e a responsabilização de procuradores por atos de improbidade administrativa. Revista da AGU, n. 42, out./dez. 2014, p. 169-200.

Advocacia Pública. Belo Horizonte: Fórum, 2015.

Direito, processo e justiça: o processo como mediador adequado entre o direito e a justiça. Salvador: Juspodivm, 2013.

Poder público, litigiosidade e responsabilidade social. Fórum Administrativo de Direito Público, Belo Horizonte, ano 11, n.126, ago. 2011.

MAFFETONE, Sebastiano; VECA, Salvatore. A ideia de Justiça de Platão a Rawls. Tradução de Karina Jannini. São Paulo: Martins Fontes, 2005.

MAZZEI, Rodrigo Reis. Código Civil de 2002 e o Judiciário: Apontamentos na aplicação das Cláusulas Gerais. In.: DIDIER JÚNIOR, Fredie; MAZZEI, Rodrigo Reis [Coord.]. Reflexos do Novo Código Civil no Direito Processual. Salvador: Juspodivm, 2006.

MELLO, Celso Antônio Bandeira de. A noção jurídica de 'interesse público'. In.: MELLO, Celso Antônio Bandeira de. Grandes Temas de Direito Administrativo. São Paulo: Malheiros, 2010.

MELLO, Celso Antônio Bandeira de. Curso de direito administrativo. 27. ed. São Paulo: Malheiros, 2010.

MITIDIERO, Daniel Francisco. Colaboração no processo civil: pressupostos sociais, lógicos e éticos. São Paulo: Revista dos Tribunais, 2009.

Processo civil e Estado Constitucional. Porto Alegre: Livraria do Advogado, 2007.

MITIDIERO, Daniel Francisco; ZANETI JÚNIOR, Hermes. Introdução ao estudo do processo civil: primeiras linhas de um paradigma emergente. Porto Alegre: SAFE, 2004.

MOREIRA NETO, Diogo de Figueiredo. A responsabilidade do advogado de Estado. Revista da APES - Temas de direito público, a importância da atuação da advocacia pública para a aplicação do direito, Salvador: Juspodivm, v. 2, 2009.

NADER, Paulo. Introdução ao estudo do direito. Rio de Janeiro: Forense, 1999.

NERY JUNIOR, Nelson e NERY, Rosa Maria Andrade. Código de Processo Civil Comentado. 9. ed. São Paulo: Revista dos Tribunais, 2006.

PIERCE, Charles Sanders. Semiótica. Tradução de José Teixeira Coelho Neto. São Paulo: Perspectiva, 1990. 
OLIVEIRA, José Roberto Pimenta. Improbidade administrativa e a sua autonomia constitucional. Belo Horizonte: Fórum, 2009.

OSÓRIO, Fábio Medina. Direito administrativo sancionador. 4. ed. São Paulo: Revista dos Tribunais, 2011. Improbidade dos fiscalizadores. Revista IOB de direito administrativo, v. 3, n. 29, p. 49-60, maio, 2008.

REALE, Miguel. Lições Preliminares de Direito. 24. ed. São Paulo: Saraiva, 1998.

REALE, Miguel. O Direito como experiência: introdução à epistemologia jurídica. 2. ed. São Paulo: Saraiva, 1992. SANTOS, Boaventura de Sousa; MARQUES, Maria Manoel Leitão; e PEDROZO, João. Os tribunais nas sociedades contemporâneas. Revista Brasileira de Ciências Sociais, ano 11, nº 30, fev. 1996.

SAUSSURE, Ferdinand de. Escritos de lingǘstica geral. Tradução de Carlos Augusto Leuba Salum e Ana Lúcia Franco. São Paulo: Cultrix, 2002.

STRECK, Lênio Luiz. Verdade e consenso: constituição, hermenêutica e teorias discursivas. Rio de Janeiro: Lumen Juris, 2006.

TUCCI, José Rogério Cruz e. Precedente judicial como fonte do Direito. São Paulo: Revista dos Tribunais, 2004. VIANNA, Luiz Werneck; MELO, Manuel Palácios Cunha; e BURGOS, Marcelo Baumann. A judicialização da política e das relações sociais no Brasil. Rio de Janeiro: Revan, 1999.

WARAT, Luis Alberto. O direito e sua linguagem. 2. ed. Porto Alegre: SAFE, 1995.

ZAGREBELSKY, Gustavo. Il Diritto Mitte - Legge, Diritti, Giustizia. Nuova edizione. Torino: Einaudi, 1992.

ZANETI JÚNIOR, Hermes. Processo Constitucional: o modelo constitucional do Processo Civil Brasileiro. Rio de Janeiro: Lumen Juris, 2007.

ZANETIJÚNIOR, Hermes. "Processo constitucional: relações entre processo e Constituição". In.: MITIDIERO, Daniel Francisco; ZANETI JÚNIOR, Hermes. Introdução ao estudo do processo civil: primeiras linhas de um paradigma emergente. Porto Alegre: SAFE, 2004.

Trabalho enviado em 07 de março de 2017.

Aceito em 04 de julho de 2017. 